\title{
THE DETERMINANTS OF INTENTION TO SHOP ONLINE AND EFFECTS OF BRAND EQUITY ON E-STORE PATRONAGE
}

\author{
* Murat CEMBERCI \\ * Mustafa Emre CIVELEK \\ ** Edin Güçü SÖZER \\ * Istanbul Commerce University, Turkey \\ ** DenizBank A.Ş., Turkey
}

\begin{abstract}
While the penetration of the Internet in consumers' daily lives still continue with an increasing momentum, this new medium has experienced a radical transformation from being a communication tool to be an economic platform where consumers do not only communicate but also transact. In this perspective, online consumer behavior became an important area for both academics and professionals, which needs to be investigated and explored. As the Internet is a new technological channel for shopping, consumers need first to decide to use this new channel for shopping and then make their online retailer preference. Thus, online consumer behavior involves a two-step process composed of intention to shop online and selection of e-store. The purpose of this study is to develop and test a two steps online consumer behavior model which explains the dynamics of the intention and selection processes. A two staged research design has been implemented in the study. At the first stage, parallel to the existing literature, the effects of risk perceptions, technology acceptance factors, and benefit perceptions on the intention to shop online has been measured. The effect of retailer brand equity on e-store selection process has been measured on the second stage. The research hypotheses have been developed based on both the existing theoretical ground and current findings in the literature. The results of the study confirmed that risk perceptions, technology acceptance factors and benefit perceptions regarding online shopping play a decisive role in the intention of consumers to shop online. A second important finding of the study is that once consumers' involve into online shopping activity, the strength of retailers' brand equity directly affects the consumers' store preference.
\end{abstract}

Keywords :E-Commerce, Online Consumer Behavior, Store Brand Equity, Intention to Shop Online.

\section{INTRODUCTION}

Since its introduction as a communication tool, the penetration of the Internet in consumers' daily life continues without losing any momentum. In the last two decades, the Internet has experienced a radical transformation from being a communication tool to be a social and economic platform where consumers do not only communicate but interact and transact.

The number of Internet users in the world has been increased more than six times since the beginning of 21st Century and reached at 2.3 billion users (Internet World Stats, 2011). Increasing number of Internet users around the world and narrowing digital divide in both national and international level (Vijayasarathy and Jones, 2000), are the two important factors which supported the introduction and development of the Internet as an economic platform. Retail e-commerce transaction volume in U.S increased more than five times since the year 2000 and reached at 165.4 billion USD in 2010 (U.S. Commerce Department, 2011). Internet shopping of consumers keeps its growth as the Internet penetration and usage rates increase around the world. According to the latest statistics from U.S. Census Bureau in 2010, the share of the Internet shopping transactions in North America reached at 4 $\%$ of total retail sales (U.S. Census Bureau, 2010). 
Due to the current potential of e-commerce, online consumer behavior became an important area for both academics and professionals, which needs to be investigated and explored. As the Internet has been introduced as a new shopping channel, consumers need first to decide to use this new channel and then make their online retailer preference. In this perspective, we can state that online consumer behavior generally includes a two-step process which is composed of intention to shop online and selection of e-store.

This study targets to shed light into the understanding of online consumer behavior and consequently contribute to the existing literature by developing and testing a combined online consumer behavior model in a Turkish consumers' context. Specifically, the study makes two important contributions to the existing literature.

The first one is the development and testing a combined model which explores the dynamics of both the intention and selection processes at the same time. Current literature includes many studies which deal with each of the processes separately. A large number of studies in the current literature target to explain the relationship between the risks, benefits, technology usage related factors and the intention of consumer to shop online (Chang and Wu, 2012; Turan, 2012; Rishi, 2010). On the other hand, another group of studies deal with the identification of factors which affect the e-store preference of consumers (Jones and Kim, 2010; Jeong et. all, 2009; Koo et. all, 2008). In addition to the existing studies, this study targets to provide a complete understanding of the whole process and consequently fills the gap in the current literature by presenting a unified two staged online consumer behavior model.

Secondly, current literature does not include sufficient number of studies which explore the dynamics of online consumer behavior in developing countries like Turkey (Turan, 2012). Thus, this study contributes also to the development of the literature in a developing country context by conducting the research in Turkey.

\section{Growing Internet penetration and e-commerce volume in Turkey}

The development of the Internet penetration and growth in e-commerce transactions show similar trends also in Turkey. According to the latest statistics in 2011, total number of users in Turkey reached at 35 million (BTK, 2011) and household Internet penetration rate increased to around $45 \%$ which can be reported as one of the highest among European countries (TUIK, 2011). The penetration rate among younger age groups (25-34), which are expected to use the Internet as a shopping channel more frequently, reached at $55 \%$. Parallel to the growth in Internet users, the total e-commerce volume of Turkish consumers' also showed significant increase in recent years and reached approximately at 12 Billion \$ (BKM, 2011).

\section{Need for deeper analysis of the two-steps online consumer behavior}

Starting from the full part of the glass, the current penetration statistics as well as retail e-commerce volume, both in the World and in Turkey, show that the Internet has already been qualified as an important platform for economic transactions. According to the latest forecast published by Forrester Research, the volume of retail e-commerce is expected to reach at 327 billion USD in 2016 and will constitute around $9 \%$ of total retail sales in North America (Website Magazine, 2012). The expected figures show that the Internet as a standalone retail channel will keep increasing its share on the overall sales and will challenge the dominance of brick-and-mortar stores in several product categories.

Despite the potential of the Internet as a standalone sales channel in retail segment, the statistics show that there is a large gap between the number of the Internet users and with those using Internet as a shopping channel. Large numbers of consumers and Internet users have drawbacks and hesitations to use this new channel for their purchases (Passyn et. all, 2011). Many researchers argue that the growth performance in online shopping volume is still below the initial expectations (Hannah and Lybecker, 2010; Anckar and D'Incau, 2002; Prabhaker, 2000; Szymanski and Hise, 2000). 
Based on the current situation, we can confidently state that consumer behavior regarding online shopping involves a two-step process composed of intention to shop online and selection of e-store. In order to be a customer of an online store, consumers should decide first to shop online. Thus, the first step of consumer behavior is related to their intention to shop online. This step of consumer decision making needs to be investigated to fully understand the whole process. At the second step, it is crucial to understand how consumers make their e-store selection before their online purchases.

In the following sections, after the review of the current literature, the factors which affect e-shopping intentions of the consumers and the determinants of e-store selection are explained. After providing the theoretical framework, which includes proposed research model and hypothesis, the relationships between the variables in the model are analyzed and finally the findings are explained and discussed, together with the practical managerial implications. The study is completed with the explanation of limitations and suggestions for future research.

\section{LITERATURE REVIEW}

\section{First stage of online consumer behaviour: Factors affecting e-shopping intention}

Every transaction in the market whether it is offline or online, is an exchange of values between at least two parties (Bagozzi, 1975) and its acceptance by any of the parties depends on the cost-benefit analysis for each specific transaction (Civelek and Sözer, 2003). Factors which affect consumers' intention to use Internet as a shopping channel became an important point of interest among both marketing academicians and practitioners. Current literature includes many academic studies which examine the role of several factors which are expected to affect the intention of consumers towards online shopping (Chang and Wu, 2012; Turan, 2012; Rishi, 2010; Ling et. all, 2010). Parallel to the current theoretical ground in marketing and existing e-commerce literature, the factors which affect online shopping intention of consumers can be classified into three main groups. These groups of factors can be listed as Risk Perceptions, Technology Acceptance Factors, and Benefit Perceptions.

\section{Risk Perceptions Of Consumers}

Every market transaction, which includes an exchange of values, holds two types of risks from the marketing perspective: Real and Perceived Risk. Based on the definition in Oxford English Dictionary (1965), real risk is defined as "the exposure to the possibility of loss, injury, or other adverse or unwelcome circumstance; a chance or situation involving such a possibility". In other words, objective risk is the one which really exists (Cunningham, in Cox, 1967, p. 82). The level of exposed risk (real) in a market transaction is totally dependent on the nature of the transaction decision (Taylor, 1974). On the other hand, perceived risk is the one which exist in consumer's mind and may lead them to overestimate or underestimate the real risk (Sitkin and Pablo, 1992). It is defined as the functional and psychological risk a consumer feels she is taking when purchasing a product or service (Dowling and Staelin, 1994). In other words, it is related to the both nature and amount of risk perceived by consumers when they make a purchase decision (Cox and Rich, 1964). Perceived risk plays a role in all major types of consumer behavior from complex buying behavior to variety seeking behavior independent from involvement level (Assael, 1981). Whether the real risk exists or not, the behaviors of consumers are determined by the level of perceived risk (Bauer, in Hancock, 1960, p. 389). In other words, when the risks are not perceived, whether they really do exist or not, will not have any effect on consumer behavior (Kovacs et. all, 2011).

Current literature on perceived risk includes several classifications made by several authors. Cunningham (1967) proposed one of the earliest classifications which included six dimensions of perceived risk. According to him, perceived risk is composed of performance, financial, time, safety, social and psychological risk dimensions. Cox and Rich (1964) focused on performance and psychological dimensions of perceived risk. The socioeconomic risk dimension which combines social and economic risk perceptions of consumers has been used for a first time by Perry and Hamm (1969). Roselius (1971) categorized four types of losses - Time, Hazard, Ego and Financial - as the consequences of several risks. Parallel to the previous literature, Garner (1986) proposed and explained six dimensions of perceived risk including Social, Financial, Physical, Performance, Time 
and Psychological risks. Although the review of the current literature shows that that there is still a lack of common categorization (Kovacs et. all, 2011), in the framework of online shopping, perceptions associated with product category, financial and security risks are proposed more intensively than other dimensions (Almousa, 2011; Bhatnagar et. all, 2000). For the purpose of this study and based on the current literature on online consumer behavior, we include product and financial risk perceptions as the individual parts of Risk Perceptions into the research model.

\section{Technology Acceptance Factors}

As every new technology and user application experiences a diffusion and evaluation process before being accepted and used by the target consumers (Rogers and Rogers, 2003), the acceptance of the Internet as a new shopping channel follows the same pattern. The fragmented structure of consumer markets (Sözer, 2009) and consequently the existence of micro segments with different consumer traits result in different attitudes of consumers towards Internet usage as a shopping channel. The adoption process of new technological user systems has been explained by Technology Acceptance Model (TAM) developed by Davis (1986). The model explains and predicts user behavior towards a new technological application. The adoption process of the Internet as a shopping channel lies within the boundaries of Technology Acceptance Model (TAM). In the original model, the two independent variables, perceived ease of use and perceived usefulness, are modeled to be an effect on the dependent variable usage. The revised model included intention as a mediating variable between independent variables and usage as the dependent variable (Davis et. all, 1989).

Current literature includes many studies which tested and confirmed the reliability of the model in various contexts (Al Zubaidi and Al-Alnsari, 2010; Zhang and Prybutok, 2003; Straub et. all, 1997; Adams et. all, 1992). Based on the current literature, this study incorporates the two independent factors - Ease of Use and Usefulness - of Technology Acceptance Model (TAM) into the research model under the grouping of Technology Acceptance Factors.

\section{Benefit Perceptions Of Consumers}

In normal circumstances, every online market transaction is expected to occur only in cases where the result of the value equation for each party is positive (Civelek and Sözer, 2003). In other words, benefits in a market transaction should outweigh the sum of costs and risk associated with this particular transaction. In today's postmodern markets where consumers became more sophisticated and demanding (Sözer, 2009), they look for more value and increased benefits in terms of money, time, effort and space (Seth and Sisodia, in Peterson, 1997, p. 17).

Based on the current literature, benefits in terms of convenience, economy and time can be listed as the most cited ones in an online context (Forsythe et. all, 2006; Childers et. all, 2001; Szymanski and Hise, 2000). Parallel to the current literature and for the purpose of this study, three types of benefit perceptions related to shopping flexibility, product selection and shopping convenience are included into the research model under the group of Benefit Perceptions.

Shopping Flexibility includes the benefits which are provided by the online shopping environment such as shopping opportunity without physical boundaries and having no time constraints in shopping times.

Second benefit type, Product Selection, includes the benefits which are provided by the online shopping environment such as a large range of products offered, many alternatives available and extended information presented about products.

Convenience benefits are mostly related to the physical effort savings which consumer gets in shopping activities (Brown, 1990). Convenience has been regarded as one of the most important benefits which are provided by the Internet (Chang and Liu, 2009). The five convenience benefits which are proposed by Brown (1989) in an online context include time, place, acquisition, use, and execution dimensions.

Based on the current literature and for the purpose of this study, Shopping Convenience Benefits includes physical and psychological benefits such as no waiting time in stores, easy buying process and no embracement if the store is left without any purchases. 


\section{Shopping orientations and Internet experience as moderating factors of intention}

\section{Shopping Orientations}

Shopping orientations are expected to be an important antecedent of online consumer behavior (Swaminathan et. all, 1999). Current literature includes the classification of shopping orientations in the online context. Vijayasarathy and Jones (2000) proposed seven shopper consisting of in-home shoppers, economic shoppers, mall shoppers, personalized shoppers, ethical shoppers, convenience shoppers and enthusiastic shoppers. The authors defined in-home shoppers as those consumers who prefer to shop from home using catalog and e-mail shopping channels. A mall shopper has been defined as a consumer who prefers to shop directly in malls. On the other hand, the authors define personalized shoppers as those consumers who prefer to shop where they knew the salespeople. They categorize ethical shoppers as consumers who prefer to shop in local stores to promote the community and convenience shoppers as consumers who look for convenience in their shopping activities. Finally, the authors identify enthusiastic shoppers as consumers who enjoy shopping as an activity. Based on the current literature and for the purpose of this study, two shopping orientations - Home Shoppers and Store Shoppers, - have been incorporated into the research model as the moderating factor between independent variables and intention to shop online.

\section{Internet Experience}

The relationship between Internet experience and intention to use Internet as a shopping channel has been examined in various studies (Citrin et. all, 2000; Lohse et. all, 2000). Internet experience increases as the frequency and duration of the Internet usage increases (Emmanouilides and Hammond, 2000). Many studies confirm that once consumers become more familiar with the Internet channel, effects of the factors are moderated based on the experience level (Citrin et. all, 2000; Lohse et. all, 2000). Based on the current literature and for the purpose of this study, Internet experience has been incorporated into the research model as the moderating factor between independent variables and intention to shop online.

\section{Second stage of online consumer behaviour: factors affecting e-store patronage}

The second stage of online consumer behavior includes the "Selection Process" of the e-store in order to involve into an exchange transaction with a commercial party. The selection process of how consumers make their choices about retail stores has been an important point of interest for researchers since many years. One of the pioneer models proposed was from Monroe and Guiltinan (1975) where consumer store choice is explained as the function of opinions toward shopping, budgeting, store attributes and consumer perceptions about the store. Shopping orientations (Darden et. all, 1980) and consumer's social characteristics (Bellenger and Moschis, 1982) are other dimensions which are included into the store selection process literature.

Review of the current literature which analyzes the store selection process of consumers show that there are mainly three groups of factors which are proposed to play a role in the selection process. These groups are consumer characteristics, store characteristics and consumer perceptions. Consumer characteristics included demographic and social characteristics such as gender, education, socioeconomic status, social class and family size (Bellenger and Moschis, 1982). Store characteristics included mainly store attributes such as merchandise, physical facilities, store atmosphere, price and location (Yavas, 2003; Doyle and Fenwick, 1974; Lindquist, 1974). Consumer perceptions are also an important group of factors which is composed of store image, service quality and customer satisfaction (McGoldrick, 2002; Osman, 1993; Marks, 1976).

Review of the studies on the consumer store selection process in the online context shows that web store atmospherics and consumer trust were the two mostly focused factors. Web store atmospherics included the perception of consumers related to design, quality, and convenience of the web site (Richard, 2005; Eroglu et. all, 2003; Dailey and Heath, in Hock and Meyer, 1999, p.245). Trust is the second important factor which is proposed to play an important role in online store selection 
(Liebermann and Stashevsky, 2002), where consumers' risk perceptions related to online shopping are higher than traditional retail stores.

Careful review of the current literature shows that the factors which are proposed to be effective in the both the conventional and online stores selection of consumers are the natural parts which constitute a powerful brand perception of consumers. A strong brand means establishing a superior value in consumers' minds and being unique compared to competitors. As a result, consumers react in a more favorable way to the firm's marketing efforts (Keller, 2003). Brand equity construct measures this unique brand position in consumer's mind. Brand equity comprises four sets of assets - brand awareness, associations linked to the brand, perceived quality, and brand loyalty (Aaker, 1991). The level and magnitude of these assets in consumer's mind determine the equity of the brand.

Brand awareness is defined as the ability of a potential buyer to recognize or recall that a brand is a member of a certain product category and creates value for a brand by taking the brand into consideration list of consumer, by being an anchor to which other associations can be attached and by being signal of consumer commitment (Aaker, 1991). Brand associations, are defined as "anything linked in memory to a brand" which create value for the brand by helping to process or retrieve information, by differentiating the brand, by providing reasons to buy and by creating positive attitudes (Aaker, 1991). When these associations come together in a meaningful way, they create the brand image, which is a part of brand knowledge, together with brand awareness (Keller, 2001). Perceived quality, the third dimension of brand equity, influences consumer decision making and encourage them to purchase the brand in question rather than competitors' brands (Yasin et. all, 2007). Brand equity is dependent mostly on brand loyalty (Aaker, 1996); where a large and loyal consumer base yields future cash flows, which in turn positively affect the value of the business.

Finally, current literature also adapts the brand equity concept into the retail store research stream. "Customer Based Store Equity" (Hartman and Spiro, 2005) and "Retailer Equity" (Arnett et. all, 2003) are the two adaptations into retailing literature. Pappu and Quester (2006) contributed to the research stream by developing "Consumer-Based Retailer Equity" which is composed of four dimensions. They defined retailer brand equity as "the value associated by the consumer with the name of a retailer, as reflected in the dimensions of retailer awareness, retailer associations, retailer perceived quality and retailer loyalty.

Based on the current literature and for the purpose of this study, retailer brand equity construct has been included as the determinant factor of the consumers' patronage intentions towards the online store.

\section{PROPOSED RESEARCH MODEL AND HYPOTHESIS}

This present study goes one step further and targets to contribute to the existing literature by proposing a model which combines the two steps of online consumer behavior by first identifying the factors which affect consumers' decision to shop online and then by explaining how consumers choose the online store.

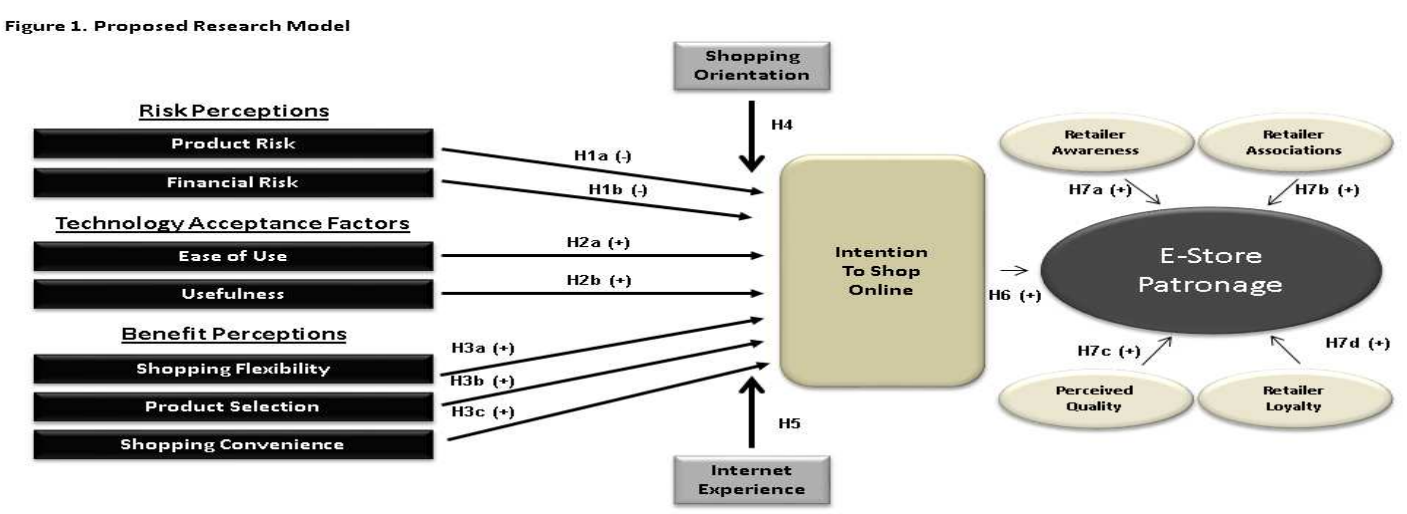

Figure 1: Proposed research model and hypothesis 


\section{Factors affecting consumers' intention to shop online}

Factors affecting the intention of consumer to shop online are classified into three groups under the name of Risk Perceptions, Technology Acceptance Factors, and Benefit Perceptions.

The first group, Risk Perceptions, is composed of Product and Financial Risk perceptions of consumers. Many studies confirmed the effect of consumers' risk perceptions on online shopping intention (Bianchi and Andrews, 2012; Chang and Wu, 2012; Pi and Sangruang, 2011; Lee and Huddleston, 2009; Jay et. all, 2002; Bhatnagar et. all, 2000). Based on the findings in the current literature and the classifications of perceived risk types in this context, we propose the following hypothesizes:

H1a. Higher the perceived product risk of consumers towards online shopping, the less will be their intention to shop online.

H1b. Higher the perceived financial risk of consumers towards online shopping, the less will be their intention to shop online.

The second group, Technology Acceptance Factors, is composed of consumer's Ease of Use and Usefulness Perception towards the Internet as a shopping channel. Studies which are conducted to validate the Technology Acceptance Model (TAM) confirmed the effect of these factors in channel selection (Al Zubaidi and Al-Alnsari, 2010; Liao and Shi, 2009; Zhang and Prybutok, 2003; Straub et. all, 1997; Adams et. all, 1992). Based on these findings in the current literature we propose the following hypothesizes:

H2a. Positive perception of Ease of Use by consumers will lead to higher levels of intention to shop online.

H2b. Positive perception of Usefulness by consumers will lead to higher levels of intention to shop online.

The third group, Benefit Perceptions, is composed of Shopping Flexibility, Product Selection and Shopping Convenience benefit perceptions of consumers. Many studies in the literature confirmed the effect of consumers' benefit perceptions on online shopping intention (Chen-Yu and Seock, 2002; Szymanski and Hise, 2000). Based on the findings in the current literature and the classifications of perceived benefit types in this context, we propose the following hypothesizes:

H3a. Higher the perceived shopping flexibility of consumers towards online shopping, the higher will be their intention to shop online.

H3b. Higher the perceived product selection benefit of consumers towards online shopping, the higher will be their intention to shop online.

$\mathrm{H} 3 \mathrm{c}$. Higher the shopping convenience benefit of consumers towards online shopping, the higher will be their intention to shop online.

\section{Moderating effects of shopping orientation and Internet experience}

The current literature includes studies which propose and confirm the moderating effect of both Shopping Orientations and Internet Experience on the Intention to Shop Online (Citrin et. all, 2000; Lohse et. all, 2000; Swaminathan et. all, 1999). Based on the current findings, we propose the following hypothesis.

H4. Shopping Orientation of consumer will have a moderating effect on the intention to shop online.

H5. Internet Experience of consumer will have a moderating effect on the intention to shop online.

\section{The relationship between intention to and actual participation into e- Shopping}

Many studies in the current literature explored the relationship between the intention and actual consumer behavior and reported the positive relationship (De Cannière, 2010; Gill et. all, 2005; Ajzen, 2002). Consumer intentions to use the Internet as a shopping channel are also found to be a significant 
predictor of consumers' actual participation in online transactions (Pavlou and Fygenson, 2006). Based on the findings in the current literature, we propose the following hypothesis:

H6. Higher the intention to shop online, the higher will be the chance of actual participation into the online shopping.

\section{Factors affecting consumers' online store selection}

For the purpose of this study and based on the current literature, retailer brand equity has been proposed to affect consumers' online store selection. Many studies in the literature confirmed the positive effect of customer based brand equity on the consumers' brand selection and purchase intention (Bian and Liu, 2011; Huang et. all, 2011; Chang and Liu, 2009). Based on the findings, we propose the following hypothesis.

H7. The strength of online store's retailer brand equity will have a positive effect on consumers' patronage intentions.

H7a. Higher the brand awareness of the retailer, the higher will be the consumers' patronage intentions.

H7b. More positive the associations in consumers' mind linked to the retailer's brand, more will be the likelihood of consumers' patronage intentions towards the retailer.

H7c. Higher the perceived quality of the retailer, the higher will be the consumers' patronage intentions.

H7d. Higher the loyalty of the consumer towards the retailer's brand, the higher will be the consumers' patronage intentions.

\section{RESEARCH METHODOLOGY}

\section{Measurement of variables}

\section{Factors Affecting Intention To Shop Online}

The research model includes three groups of independent variables composed of seven dimensions. The scales employed in the measurement of Risk Perception have been adopted from the work of Forsythe et. all, (2006). Authors reported 0.84 and $0.89 \alpha$ scores for Product and Financial risk perceptions, respectively. Technology Acceptance Factors have been measured by employing the scales from Devaraj et. all, (2002). Authors reported $0.88 \alpha$ score for both Ease of Use and Usefulness dimensions. Scales of Benefit Perceptions have been also adopted from the work of Forsythe et. all, (2006). Authors reported $0.898,0.797$ and $0.780 \alpha$ scores for Shopping Flexibility (Original name is Shopping Convenience), Product Selection and Shopping Convenience (Original name is Ease of Shopping) benefit perceptions, respectively.

\section{Factors Affecting Consumers' Online Store Selection}

The research model includes retailer brand equity construct which is proposed to affect e-store selection of consumers. Retailer brand equity variable is measured by employing the multidimensional scale constructed and validated by Pappu and Quester (2006). The scale is composed of statements aimed at measuring the four retailer brand equity dimensions, namely retailer brand awareness, retailer brand associations, retailer perceived quality and retailer brand loyalty. Pappu and Quester (2006) reported strong construct validity for this scale. The internal reliability check of our scale yielded alpha scores of $0.8835,0.8633,0.8922$ and 0.7988 for retailer brand awareness, retailer brand associations, retailer perceived quality and retailer brand loyalty, respectively. Due to the reported validity of the subject scale by researchers in the field and the restrictions discussed in the existing literature on measuring brand equity, a fourteen-item 7 point Likert type scale is employed to measure brand equity. The overall store brand equity score of a subject is computed as a summated scale up to ninety eight points for a given brand. 


\section{Intention to shop online and consumers' online store selection}

Each of the two dependent variables in the model, Intention to Shop Online and E-Store Patronage, are measured by the single item seven points Likert Type scale which are developed by the authors for the purpose of this study.

\section{Moderating Variables: Shopping Orientations And Internet Experience}

Two moderating variables in the research model, namely Shopping Orientations and Internet Experience, have been measured by two nominal scaled single item statements developed by the authors. Content and face validity checks are done for both variables and confirmed accordingly.

\section{Research design}

The research was conducted in a campus of a private University in Istanbul, Turkey. The subjects of this study were the undergraduate students of the University. Due to their propensity to use the Internet, they were selected as the subject group. The group was composed of members from twenty different course classes in several programs of the University faculties. Twenty classes were identified via a random sampling method from the total class list of the university. Total number of the subjects was 406.

The study was composed of two stages. Prior to the first stage, the research instrument was tested in order to measure the face validity. The self-administered pilot questionnaire was prepared and then tested on 50 students of the Faculty of Business Administration. The results showed that some statements needed to be revised, because of poor face validity. All the statements which required attention were then modified appropriately.

In the first stage of the study, the target was to explore the relationship between the several independent factors and the Intention to Shop Online. The questionnaire also included several questions regarding the subjects' Internet usage frequency, online shopping experience and their shopping orientations. Subjects were gathered together in different classrooms and the first section of the questionnaires was distributed to them. The questionnaire included 35 questions and all subjects completed their answers within 25 minutes.

In the second section, the same subject group have been distributed the second questionnaire which targets to measure the effect of store brand equity on the e-store patronage intention of the subjects. In this section, subjects are asked to mark three e-stores (Store A, Store B and Store C) from the list of ten stores in the questionnaire and rank these three e-stores based on their preference. Following the ranking procedure, subjects are asked to answer the questions which measured the store brand equity for these three e-stores they ranked. The questionnaire included 47 questions and all subjects completed their answers within 35 minutes.

\section{RESEARCH RESULTS}

After the completion of the field study, the questionnaires have been collected and prepared for the statistical analysis. In all statistical analyses, the Statistical Package for Social Sciences (SPSS) version 11.5 has been used.

\section{Composition of the subject group}

The subject group was composed of undergraduate students of a private University in Istanbul, Turkey. The gender distribution was in favor of male subjects (57.4\%) compared to females ones $(42.6 \%)$. The major part of the subject group (84.7\%) was regularly using Internet and $68.2 \%$ of the subjects were involved in an online shopping transaction before.

\section{Grouping of independent variables}

The proposed research model of the study consisted of seven independent factors composed of twenty eight different variables. The result of the analysis on the intra relationship of the twenty eight different variables showed statistically significant relationships. In this perspective, it is thought that grouping of these elements would be useful for having a manageable number of variables in the study. 
In order to reduce the independent sponsorship variables into a manageable number of factors, a Principal Component Analysis (PCA) has been conducted. All twenty eight independent sponsorship variables are included in the analysis. The results of the factor analysis resulted in the creation of six factors having an explanatory power of $63 \%$, a Kaiser-Meyer-Oklin test score of 0,907, which shows that the data used is the homogenous collection of variables, and a significant Bartlett test of Sphericity.

Based on the results of the PCA analysis, the original number of factors has been reduced from seven to six with the merger of two independent factors, Ease of Use and Usefulness, under the name of Technology Acceptance Factors. The list of the independent factors, their explanations and their respective Cronbach's $\alpha$ score which show their internal reliability strengths are summarized in the following table.

Table 1: List of grouped variables and Cronbach's $\alpha$ scores

\begin{tabular}{|c|c|l|c|}
\hline & Variable Name & \multicolumn{1}{c|}{ Definition } & Cronbach's $\boldsymbol{\alpha}$ Score \\
\hline 1 & $\begin{array}{c}\text { Product Risk } \\
\text { Perception }\end{array}$ & $\begin{array}{l}\text { Subjects' risk perception in online shopping transactions } \\
\text { related to the product (No physical contact, no trial). }\end{array}$ & 0,7329 \\
\hline 3 & $\begin{array}{c}\text { Financial Risk } \\
\text { Perception } \\
\text { Acceptance Factors }\end{array}$ & $\begin{array}{l}\text { Subjects' financial risk perception in online shopping } \\
\text { transactions (Fraud, wrong choice). }\end{array}$ & 0,7559 \\
\hline 4 & $\begin{array}{c}\text { Subjects' perception of internet as a shopping channel from } \\
\text { usefulness and ease of use perspectives. }\end{array}$ & 0,8954 \\
\hline 5 & $\begin{array}{c}\text { Product Selection } \\
\text { Benefits }\end{array}$ & $\begin{array}{l}\text { Subjects' perception on the product related benefits (Wide } \\
\text { range, many alternatives, fast information) which are } \\
\text { provided by online shopping environment. }\end{array}$ & $\begin{array}{l}\text { Subjects' perception on the flexibility (No physical } \\
\text { boundaries, no time constraint) which is provided by online } \\
\text { shopping environment. }\end{array}$ \\
\hline 6 & $\begin{array}{c}\text { Shopping Convenience } \\
\text { Benefits }\end{array}$ & $\begin{array}{l}\text { Subjects' perception on the convenience (No waiting time, } \\
\text { multiple store visits at once) which is provided by online } \\
\text { shopping environment. }\end{array}$ & 0,8286 \\
\hline
\end{tabular}

\section{The determinants of intention to shop online}

In order to understand the relationship between the independent factors and Intention to Shop Online, a two staged analysis has been made. In the first stage, the relationship between each independent factor and Intention to Shop Online has been measured using Pearson correlation analysis. The result of the analysis confirmed that all independent factors have significant relationships with the Intention to Shop Online. Technology Acceptance Factors showed highest positive relationship $[\mathrm{r}(406)=0.691$, $\mathrm{p}=.000]$ with the Intention to Shop Online. Shopping Flexibility Benefits [r (406) $=0.578, \mathrm{p}=.000]$, Product Selection Benefits [r (406) $=0.476, \mathrm{p}=.000]$, and Shopping Convenience Benefits [r (406) $=0.420, \mathrm{p}=.000 \mathrm{]}$ also showed positive relationships and followed Technology Acceptance Factors. Risk Perceptions of the subjects, namely Financial Risk Perception [r (406) $=-0.481, \mathrm{p}=.000]$ and Product Risk Perception [r (406) $=-0.099, \mathrm{p}=.046]$, also showed significant negative relationships with the Intention to Shop Online. Based on these results, Hypothesis H1a, H1b, H3a, H3b and H3c are accepted.

As the result of the PCA analysis resulted in the unification of "Ease of Use" and "Usefulness" variables under the name of "Technology Acceptance Factors", the restructured version of Hypothesis 2 (Unification of $\mathrm{H} 2 \mathrm{a}$ and $\mathrm{H} 2 \mathrm{~b}$ ) has also been accepted based on the statistically significant result of the analysis. 
The following table shows the summary of the findings regarding the relationship between independent variables and Intention to Shop Online.

The second stage of the analysis regarding the relationship between the independent factors and Intention to Shop Online included the overall examination of the model. In order to predict the changes in the Intention to Shop Online when some changes occur in the independent factors, the multiple regression analysis has been conducted. The analysis included all independent factors which have been found a significant relationship with the Intention to Shop Online in hypothesis testing. The result of the Multiple Regression Analysis indicated that $54.5 \%$ of the variance in the Intention to Shop Online is explained by the model. Technology Acceptance Factors, Financial Risk Perception, Shopping Flexibility Benefits and Product Selection Benefits were the four statistically significant predictors. Technology Acceptance Factors $(\beta 0,424)$ are found to be the strongest predictor which is followed by Financial Risk Perception ( $\beta$-0,191), Shopping Flexibility Benefits $(\beta$ 0,165), and Product Selection Benefits ( $\beta$ 0,085), respectively.

Table 2: Relationship between independent variables and intention to shop online

\begin{tabular}{|c|c|c|c|c|}
\hline Code & Variable Name & Hypothesis & $\begin{array}{l}\text { Relationship } \\
\text { Direction }\end{array}$ & $\begin{array}{c}\text { Pearson Correlation } \\
\text { Results }\end{array}$ \\
\hline $\mathrm{H} 1 \mathrm{a}$ & $\begin{array}{l}\text { Product Risk } \\
\text { Perception }\end{array}$ & $\begin{array}{l}\text { The higher the perceived product risk } \\
\text { of consumers towards online shopping } \\
\text { is, the less their intention to shop online } \\
\text { will be. }\end{array}$ & Negative & $\begin{array}{c}\text { Significant } \\
{\left[\mathrm{r}(406)=-0.099^{*}, \mathrm{p}=.046\right]}\end{array}$ \\
\hline $\mathrm{H} 1 \mathrm{~b}$ & $\begin{array}{l}\text { Financial Risk } \\
\text { Perception }\end{array}$ & $\begin{array}{l}\text { The higher the perceived financial risk } \\
\text { of consumers towards online shopping } \\
\text { is, the less their intention to shop online } \\
\text { will be. }\end{array}$ & Negative & $\begin{array}{c}\text { Significant } \\
{\left[\mathrm{r}(406)=-0.481^{* *}\right.} \\
\mathrm{p}=.000]\end{array}$ \\
\hline $\mathrm{H} 2$ & $\begin{array}{l}\text { Technology } \\
\text { Acceptance } \\
\text { Factors }\end{array}$ & $\begin{array}{l}\text { Higher the Technology Acceptance of } \\
\text { the customer towards Online Channel, } \\
\text { the higher will be their intention to } \\
\text { shop online. }\end{array}$ & Positive & $\begin{array}{c}\text { Significant } \\
{\left[\mathrm{r}(406)=0.691^{* *}, \mathrm{p}=.000\right]}\end{array}$ \\
\hline $\mathrm{H} 3 \mathrm{a}$ & $\begin{array}{l}\text { Shopping } \\
\text { Flexibility } \\
\text { Benefits }\end{array}$ & $\begin{array}{l}\text { The higher the perceived shopping } \\
\text { flexibility of consumers towards online } \\
\text { shopping is, the higher their intention } \\
\text { to shop online will be. }\end{array}$ & Positive & $\begin{array}{c}\text { Significant } \\
{\left[\mathrm{r}(406)=0.578^{* *}, \mathrm{p}=.000\right]}\end{array}$ \\
\hline $\mathrm{H} 3 \mathrm{~b}$ & $\begin{array}{l}\text { Product } \\
\text { Selection } \\
\text { Benefits }\end{array}$ & $\begin{array}{l}\text { The higher the perceived product } \\
\text { selection benefit of consumers towards } \\
\text { online shopping is, the higher their } \\
\text { intention to shop online will be. }\end{array}$ & Positive & $\begin{array}{c}\text { Significant } \\
{\left[\mathrm{r}(406)=0.476^{* *}, \mathrm{p}=.000\right]}\end{array}$ \\
\hline \multirow[t]{2}{*}{$\mathrm{H} 3 \mathrm{c}$} & $\begin{array}{l}\text { Shopping } \\
\text { Convenience } \\
\text { Benefits }\end{array}$ & $\begin{array}{l}\text { The higher the shopping convenience } \\
\text { benefit of consumers towards online } \\
\text { shopping is, the higher their intention } \\
\text { to shop online will be. }\end{array}$ & Positive & $\begin{array}{c}\text { Significant } \\
{\left[\mathrm{r}(406)=0.420^{* *}, \mathrm{p}=.000\right]}\end{array}$ \\
\hline & & $\begin{array}{l}* \text { Correlation is significant at the } 0.05 \\
\text { level ( } 2 \text {-tailed). } \\
* * \text { Correlation is significant at the } 0.01 \\
\text { level (2-tailed). }\end{array}$ & & \\
\hline
\end{tabular}

The following table summarizes the findings of the multiple regression analysis. 
Table 3: The relationship between independent factors and intention to shop online

\begin{tabular}{|c|c|c|c|}
\hline Factor Name & Factor Explanation & $\begin{array}{l}\text { Standardized } \\
\text { Coefficient }(\beta)\end{array}$ & Significance \\
\hline $\begin{array}{l}\text { Technology Acceptance } \\
\text { Factors }\end{array}$ & $\begin{array}{l}\text { Subjects' perception of internet as a shopping channel from } \\
\text { usefulness and ease of use perspectives. }\end{array}$ & 0,424 & 0.000 \\
\hline $\begin{array}{l}\text { Financial Risk } \\
\text { Perception }\end{array}$ & $\begin{array}{l}\text { Subjects' financial risk perception in online shopping } \\
\text { transactions (Fraud, wrong choice). }\end{array}$ & $-0,191$ & 0.000 \\
\hline $\begin{array}{l}\text { Shopping Flexibility } \\
\text { Benefits }\end{array}$ & $\begin{array}{l}\text { Subjects' perception on the flexibility (No physical boundaries, } \\
\text { no time constraint) which is provided by online shopping } \\
\text { environment. }\end{array}$ & 0,165 & 0.001 \\
\hline $\begin{array}{l}\text { Product Selection } \\
\text { Benefits }\end{array}$ & $\begin{array}{l}\text { Subjects' perception on the product related benefits (Wide } \\
\text { range, many alternatives, fast information) which are provided } \\
\text { by online shopping environment. }\end{array}$ & 0,085 & 0.047 \\
\hline $\begin{array}{l}\text { Shopping Convenience } \\
\text { Benefits }\end{array}$ & $\begin{array}{l}\text { Subjects' perception on the convenience (No waiting time, } \\
\text { multiple store visits at once) which is provided by online } \\
\text { shopping environment. }\end{array}$ & 0,071 & 0.089 \\
\hline Product Risk Perception & $\begin{array}{l}\text { Subjects' risk perception in online shopping transactions } \\
\text { related to the product (No physical contact, no trial). }\end{array}$ & $-0,011$ & 0,755 \\
\hline & $\begin{array}{lcc}\text { Model Summary } & \text { R: , } 743 & \text { R Square: ,552 Adjusted R } \\
\text { Square: ,545 Durbin-Watson: } 1,837 & \end{array}$ & & \\
\hline
\end{tabular}

\section{Moderating effects of shopping orientation and internet experience}

Shopping Orientations and Internet Experience Level of the subjects were hypothesized to have a moderating effect on the intention to shop online. The results of the t-test confirm that Shopping Orientation type of subjects play a moderating role on the Intention to Shop Online. The analysis of the data shows that the level of Intention to Shop Online differs among Home Shoppers and Store Shoppers. Home shoppers have higher mean scores than Store Shoppers concerning the Intention to Shop Online. The results of the t-test also confirm that the difference is statistically significant [ $\mathrm{t}(383)$ $=11.8, \mathrm{p}=.000]$. Thus, Hypothesis 4 has been accepted.

Originally, the Internet Experience variable was measured in five levels ranging from no use at all to every day usage. In order to compute the independent samples t-test and to explore whether the Internet Experience plays a moderating role or not, the variable is computed into a different one as having two levels named as Low and High Experience.

The results of the t-test showed that there is no significant difference in the Intention to Shop Online levels of subjects with low and high Internet experiences [ $t(404)=-0.6, p=.512]$. Thus, Hypothesis 5 is not accepted.

\section{The relationship between intention to and actual participation into e- shopping}

The Intention to Shop Online was hypothesized to have a positive relationship with the actual participation into the online shopping. Actual participation into the online shopping has been measured with the statement of subjects regarding their plans to involve in such transactions in the near feature. In order to test this relationship, a Pearson correlation analysis has been conducted. The results of the Pearson correlation analysis confirmed that there is a strong relationship between 
Intention to and actual participation into the online shopping [r (406) $=0.763 * *, p=.000]$. Thus, Hypothesis 6 has been accepted.

\section{The effect of retailer brand equity on the e-store selection}

The comparison of the retailer brand equity scores for three preferred brands of each subject shows that the brand which is ranked as the first choice received the highest brand equity score. The means of the retailer brand equity score for the three preferred brands were 76,69 and 64 out of 98 points, respectively. The mathematical analysis shows that the equity scores of Store A, B and C are in the same order with the preference rank of these stores. In order to test the statistical significance of this difference, a repeated measures ANOVA test has been conducted. The significant result of the Mauchly's Test of Sphericity resulted into the continuation of the analysis with Greenhouse-Geisser approach. The result of the ANOVA test also confirmed that there is a significant difference between the equity scores of each retailer $[\mathrm{F}(1,871,757,695)=207,926, \mathrm{p}<0,005]$. The Pairwise comparisons of the equity scores also showed that the brand equities of Store A and B [p<0,005], Store A and C $[\mathrm{p}<0,005]$ and Store B and $\mathrm{C}[\mathrm{p}<0,005]$ are significantly different from each other without any exception. Thus, we accept Hypothesis 7 and conclude that the strength of online store's retailer brand equity will have a positive effect on consumers' patronage intentions.

Parallel to the overall brand equity score, the equity dimensions of the first rank retailer, received higher scores compared to those which are ranked as the second and third preferences. The result of the ANOVA test also confirmed that there is a significant difference between the scores of brand awareness $[\mathrm{F}(1,871,757,690)=169,004, \mathrm{p}<0,005]$, brand associations $[\mathrm{F}(1,956,792,030)=112,633$, $\mathrm{p}<0,005]$, perceived quality $[\mathrm{F}(1,833,742,294)=74,905, \mathrm{p}<0,005]$ and brand loyalty $[\mathrm{F}(1,786$, $723,266)=149,760, p<0,005]$ in each retailer brand. Pairwise comparisons of each retailer's score based on the equity dimensions also resulted in statistically significant $[\mathrm{p}<0,005]$ differences. Thus, we accept Hypothesis 7a, 7b, 7c and 7d.

In the light of these findings, the restructured and finalized research model has been summarized in Figure 2.

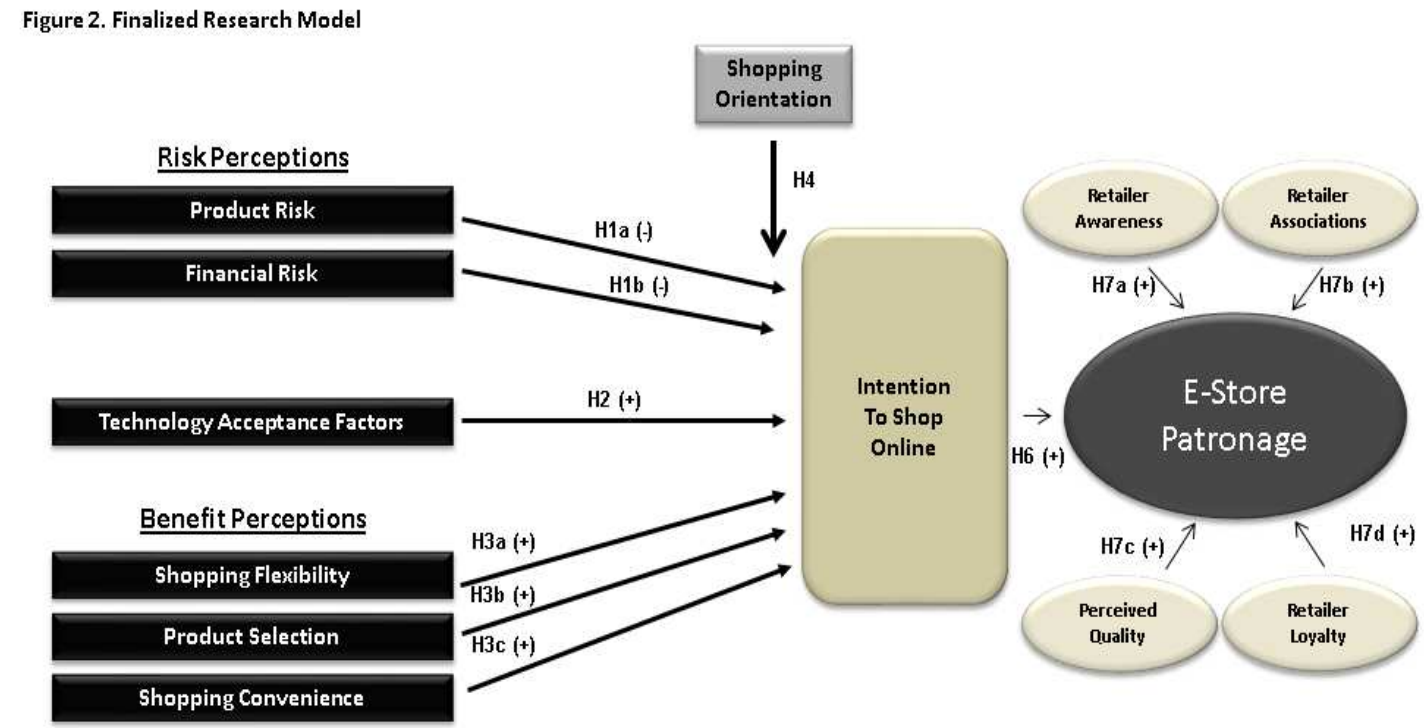

\section{Figure 2: Finalized research model}




\section{CONCLUSION AND DISCUSSION}

\section{Managerial implications}

As the online consumer behavior is composed of two independent stages which are Intention and Selection, the transformation of one person from consumer status into an online customer status requires the successful completion of both stages. Consumers should first intent to shop online and then become the real online customers of companies.

\section{Strategies for creating intention to shop online}

Parallel to the current literature, the results of this research also confirm that there are three groups of factors, namely Risk Perceptions, TAM Factors and Benefit Perceptions, which have significant relationships with the intention of the consumers to shop online. There are some strategies which have to be implemented for expanding the online consumer community by increasing their intention to shop online.

First of all, in order to minimize the risk perceptions, companies should first invest into their online channels to provide maximum effectiveness in their infrastructural and operational service levels. Delivery time, item return and refund policies, guarantees provided and other related procedures and services have to be carefully reviewed and implemented in order to minimize the product risk perception. Moreover, companies have to ensure that the latest security standards are implemented in online channels and communicated with the prospect consumers.

Secondly, in order to shift positively the perception of consumers regarding the use of online channel as a new technology and benefits associated with it, companies should communicate to the target segment the best practice cases of online customers who use online channels. Best practice cases including the convenience, simplicity and flexibility of using online channel have to be communicated to the target segment using an integrated communications approach.

\section{Retailers need strong brand equity for increasing online market share}

The second stage of online consumer behavior is the Selection process. Once consumers intent to shop online, they search for a retailer to shop online. The result of this research confirms that the strength of the retailer brand equity has a strong positive relationship with the e-store patronage of consumers. Online retailers with strong brand equity have more competitive power compared to those having weaker brand equities. In this perspective, companies need to implement strategies which will lead to the establishment of strong brand equities in order to increase their competitive power in the online market.

As it is structured both in the literature (Pappu and Quester, 2006) and in this study, the retailer brand equity is composed of four dimensions which are retailer awareness, retailer associations, perceived quality and retailer loyalty, respectively. Retailers who target to create stronger brand equities have to focus on each dimension separately and create tactical moves which will support the sustainable improvement of each dimension.

\section{Limitations of the study and suggestions for further research}

This study has targeted to shed light into the online consumer behavior from e-tailing perspective by proposing and testing a two staged online consumer behavior model. Results of the study both explained and confirmed the determinants of Intention to Shop Online as well as the effect of brand equity on the e-store selection of online consumers. However, in order to increase the generalizability of the findings, other age and occupation groups rather than students as well as other product categories rather than electronics or books can be included in further research studies. 


\section{REFERENCES}

Aaker, D. (1991), Managing Brand Equity, The Free Press, New York.

Aaker, D. (1996), Building Strong Brands, The Free Press, New York.

Adams, D. A., Nelson, R. R. and Todd, P. A. (1992), "Perceived usefulness, ease of use, and usage of information: A replication", MIS Quarterly, Vol. 16, No. 2, pp. 227-247.

Ajzen, I. (2002), Perceived behavioral control, self-efficacy, locus of control, and the theory of planned behavior, Journal of Applied Social Psychology, Vol. 32, No. 4, pp. 665-683.

Almousa, M. (2011), Perceived Risk in Apparel Online Shopping: A Multi-Dimensional Perspective, Canadian Social Science, Vol. 7, No. 2, pp. 23-31.

Al Zubaidi, H. and Al-Alnsari, A. (2010), Assessing Kuwaitis' Intention to Shop Online Using TAM, Journal of Transnational Management, Vol. 15, No. 4, pp. 293.

Anckar, B. and D'Incau, D. (2002), Value creation in mobile commerce: Findings from a consumer survey, JITTA: Journal of Information Technology Theory and Application, Vol. 4, No. 1, pp. 43-64.

Arnett, D.B., Laverie, D.A. and Meiers, A. (2003), Developing parsimonious retailer equity indexes using partial least squares analysis: a method and applications, Journal of Retailing, Vol. 79, No. 3, pp. 161-70.

Assael, H. (1981), Consumer Behavior and Marketing Action, Kent Publishing, Boston.

Bagozzi, R. P. (1975), Marketing as exchange, Journal of Marketing, Vol. 39, October, pp. 32-39.

Bauer, R. A. (1960), Consumer behavior as risk-taking”, in: Hancock R. S. (ed.), Dynamic marketing for a changing world, pp. 389-398, American Marketing Association, Chicago.

Bellenger, D. N. and Moschis G. P. A (1982), Socialization Model of Retail Patronage, in: Mitchell, A. and Abor, A. (eds.), Advances in Consumer Research, Vol. 9, No. 1, pp. 373-378.

Bhatnagar, A., Misra, S. and Rao, H. R. (2000), On risk, convenience, and Internet shopping behavior, Communications of the ACM, Vol. 43, No. 11, pp. 98-105.

Bian, J. and Liu, C. (2011), Relation between brand equity and purchase intention in hotel industry, International Journal of Services and Standards, Vol. 7, No. 1, pp. 18-34.

Bianchi, C. and Andrews, L. (2012), Risk, trust, and consumer online purchasing behaviour: a Chilean perspective, International Marketing Review, Vol. 29, No. 3, pp. 253-275.

BKM - Turkish Interbank Card Centre. (2012), E-Commerce Statistics 2011 (Online), BKM, Istanbul. Available at: http://www.bkm.com.tr (Accessed on May 2012).

Brown, L.G. (1990), Convenience in Services Marketing, Journal of Services Marketing, Vol. 4, No. 11 , pp. 53-59.

Brown, L. G. (1989), The Strategic and Tactical Implications of Convenience in Consumer Product Marketing, Journal of Consumer Marketing, Vol. 6, No. 3, pp. 13-19.

BTK- Turkish Information Technologies Association. (2012), Country Statistics 2011 (Online), BTK, Ankara. Available at http://www.tk.gov.tr (Accessed on May 2012).

Chang, M. and Wu, W. (2012), Revisiting Perceived Risk in the Context of Online Shopping: An Alternative Perspective of Decision-Making Styles, Psychology \& Marketing, Vol. 29, No. 5, pp.378.

Chang, H. H. and Liu, Y. M. (2009), The impact of brand equity on brand preference and purchase intentions in the service industries, The Service Industries Journal, Vol. 29, No. 12, pp. 1687-1706.

Chen-Yu, J.H. and Seock, Y. K. (2002), Adolescents' clothing purchase motivations, information sources, and store selection criteria: A comparison of male/female and impulse/non-impulse shoppers, Family and Consumer Sciences Research Journal, Vol. 31, No. 1, pp. 50-77. 
Childers, T., Carr, C., Peck, J. and Carson, S. (2001), Hedonic and Utilitarian Motivations for Online Retail Shopping Behavior, Journal of Retailing, Vol. 77, No. 4, pp. 511-535.

Citrin, A. V., Spritt, D. E., Silverman, S. N. and Stem, D. E. (2000), Adoption of Internet shopping: The role of consumer innovativeness, Industrial Management and Data Systems, Vol. 100, No. 7, pp. 294-300.

Civelek M. E. and Sözer E. G. (2003), Internet Ticareti: Yeni Ekososyal Sistem ve Ticaret Noktalarý, Beta, Istanbul.

Cunningham, S. M. (1967), The Major Dimensions of Perceived Risk, in Cox D. F. (ed.), Risk Taking and Information Handling in Consumer Behavior, pp. 82-108, Harvard University, Boston.

Cox, D. F. and Rich, S. U. (1964), Perceived risk and consumer decision making-the case of telephone shopping, Journal of Marketing Research, Vol. 1, November, pp. 32-39.

Dailey, L. and Heath, C. E. (1999), Bringing back your online customers: an exploration of the role of atmospherics on the web, in: Hock S. and Meyer R (eds.), Advances in consumer research, pp. 245251, Association for Consumer Research, Provo (UT).

Darden, W. R., Howell, R., and Powell, T. E. (1980), The Effect of Retail Work Experience on Shopping Orientations, Working Paper, Center for Marketing Research and Modeling, University of Arkansas, Arkansas.

Davis, F. D., Bagozzi, R. and Warshaw, P. R. (1989), User Acceptance of Computer Technology: A Comparison of Two Theoretical Models, Management Science, Vol. 35, No. 8, pp. 982-1003.

Davis, F. D. A (1986), Technology Acceptance Model for empirically testing new end-user information systems: Theory and Results, Ph.D. Thesis, Massachusetts Institute of Technology, Sloan School of Management.

De Cannière, M. H., De Pelsmacker, P. and Geuens, M. (2010), Relationship Quality and Purchase Intention and Behavior: The Moderating Impact of Relationship Strength, Journal of Business and Psychology, Vol. 25, No. 1, pp. 87-98.

Devaraj, S., Fan, M. and Kohli, R. (2002), Antecedents of B2C Channel Satisfaction and Preference: Validating E-Commerce Metrics, Information Systems Research, Vol. 13, No. 3, pp. 316-334.

Dowling, G. R. and Staelin, R. (1994), A model of perceived risk and intended risk-handling activity, Journal of Consumer Research, Vol. 21, No. 1, pp. 119- 134.

Doyle, P. and Fenwick, I. (1974), Shopping habits in grocery chains, Journal of Retailing, Vol. 50, No. Winter (1974-1975), pp. 39-52.

Emmanouilides, C. and Hammond K. (2000), Internet usage: Predictors of active users and frequency of use, Journal of Interactive Marketing, Vol. 14, No. 2, pp. 17-32.

Eroglu, S.A., Machleit, K.A. and Davis L.M. (2003), Empirical testing of a model of online store atmospherics and shopper responses, Psychology and Marketing, Vol. 20, No. 2, pp. 139-150.

Forsythe, S., Liu, C. L., Shannon, D., and Gardner, L. C. (2006), Development of a scale to measure the perceived benefits and risks of online shopping, Journal of Interactive Marketing, Vol. 20, No. 2, pp. 55-75.

Garner, S. J. (1986), Perceived Risk and Information Sources in Services Purchasing, The Mid Atlantic Journal of Business, Vol. 24, No. 2, pp. 49-58.

Gill, H., Boies, K., Finegan, J. E. and McNally, J. (2005), Antecedents of trust: Establishing a boundary condition for the relation between propensity to trust and intention to trust, Journal of Business and Psychology, Vol. 19, No. 3, pp. 287-302.

Hannah, B. and Lybecker, K. M. (2010), Determinants of Recent Online Purchasing and the Percentage of Income Spent Online, International Business Research, Vol. 3, No. 4, pp. 60-71. 
Hartman, K.B. and Spiro, R.L. (2005), Recapturing store image in customer-based store equity: a construct conceptualization, Journal of Business Research, Vol. 58, No. 3, pp. 1112-1120.

Huang, P., Wang, C., Tseng, Y. and Wang, R. (2011), The impact of brand equity on customer's purchase intention - Taking perceived value as a moderating variable, Journal of Information \& Optimization Sciences, Vol. 32, No. 3, pp. 657-672.

Internet World Stats. (2012), Internet Users 2011 Report (Online), Miniwatts Marketing Group, Bogota. Available at http://www.internetworldstats.com (Accessed on April 2012).

Jay K., Forsythe S., and Soak M. (2002), Cross cultural consumer values, needs and purchase behavior, Journal of Consumer Marketing, Vol. 19, No. 6, pp. 481-502.

Jeong, S. W., Fiore, A. M., Niehm, L. S. and Lorenz, F. O. (2008), The role of experiential value in online shopping: The impacts of product presentation on consumer responses towards an apparel web site, Internet Research, Vol. 19, No. 1, pp. 105-124.

Jones, C. and Kim, S. (2010), Influences of retail brand trust, off-line patronage, clothing involvement and website quality on online apparel shopping intention, International Journal of Consumer Studies, Vol. 34, No. 6 pp. 627-637.

Keller, K.L. (2003), Strategic Brand Management: Building, Measuring and Managing Brand Equity, Prentice Hall, New Jersey.

Keller, K.L. (2001), "Building Customer-Based Brand Equity”, Marketing Management, Vol. 10, No. 2, pp. 14-19.

Koo, D., Kim, J. and Lee, S. (2008), Personal values as underlying motives of shopping online, Asia Pacific Journal of Marketing and Logistics, Vol. 20, No. 2, pp. 156-173.

Kovacs, M., Farias, S., Moura, F. and Souza, A. (2011), Relations between Consumer Effort, Risk Reduction Strategies, and Satisfaction with the E-commerce Buying Process: The Development of a Conceptual Framework, International Journal of Management, Vol. 28, No. 1, pp. 316-329.

Lee, H. and Huddleston, P. (2009), An investigation of the relationships among domain-specific innovativeness, overall perceived risk and online purchase behavior, International Journal of Electronic Marketing and Retailing, Vol. 3, No. 1, pp.1-4.

Liao, Z. and Shi, X. (2009), Consumer perceptions of internet-based e-retailing: an empirical research in Hong Kong, The Journal of Services Marketing, Vol. 23, No. 1, pp. 24-30.

Liebermann, Y. and Stashevsky, S. (2002), Perceived risks as barriers to Internet and e-commerce usage, Qualitative Market Research, Vol. 5, No. 2, pp. 291-300.

Lindquist, J.D. (1974), Meaning of image: a survey of empirical and hypothetical evidence, Journal of Retailing, Vol. 50, No. Winter 1974-1975, pp. 29-38.

Ling, K. C., Chai, L. T. and Piew, T. H. (2010), The Effects of Shopping Orientations, Online Trust and Prior Online Purchase Experience toward Customers' Online Purchase Intention, International Business Research, Vol. 3, No. 3, pp. 63-76.

Litan R. E. and Rivlin A. M. (2001), Beyond the Dot.Coms: The Economic Promise of the Internet, Brookings Institution Press, Washington DC.

Lohse, G. L., Bellman, S., and Johnson, E. J. (2000), Consumer buying behavior on the Internet: Findings from panel data, Journal of Interactive Marketing, Vol. 14, No. 1, pp. 15-29.

Marks, R.B. (1976), Operationalizing the concept of store image, Journal of Retailing, Vol. 52, No. Fall, pp. 37-46.

McGoldrick, P. J. (2002), Retail Marketing, McGraw-Hill Education, Berkshire.

Monroe, K. B. and Guiltinan J. P. (1975), "A Path-Analytic Exploration of Retail Patronage Influences”, Journal of Consumer Research, Vol. 2, No. June, pp. 19-28. 
Osman, M. Z. (1993), A conceptual model of retail image influences on loyalty patronage behavior, The International Review of Retail, Distribution and Consumer Research, Vol. 3, No. 2, pp. 133-148.

Oxford English Dictionary. (1965), Definition of Risk, Oxford University Press, US.

Pappu, R. and Quester, P. (2006), A consumer-based method for retailer equity measurement: results of an empirical study, Journal of Retailing and Consumer Services, Vol. 13, No. 5, pp. 317-329.

Passyn, K. A., Diriker, M. and Settle, R. B. (2011), Images Of Online Versus Store Shopping: Have The Attitudes Of Men And Women, Young And Old Really Changed?, Journal of Business \& Economics Research, Vol. 9, No. 1, pp. 99-110.

Pavlou, P. A. and Fygenson, M. (2006), Understanding and predicting electronic commerce adoption: An extension of the theory of planned behavior, Management Information Systems Quarterly, Vol. 30, No. 1, pp. 115-143.

Perry, M. and Hamm, B. C. (1969), Canonical analysis of relations between socioeconomic risk and personal influence in purchase decisions, Journal of Marketing Research, Vol. 6, No. 3, pp. 351-354.

Pi, S. and Sangruang, J. (2011), The Perceived Risks of Online Shopping in Taiwan, Social Behavior and Personality, Vol. 39, No. 2, pp.275-285.

Prabhaker, P. R. (2000), Who owns the online consumer?, The Journal of Consumer Marketing, Vol. 17, No. 2, pp. 158-171.

Richard, M.O. (2005), Modeling the impact of Internet atmospherics on surfer behavior, Journal of Business Research, Vol. 58, No. 2, pp. 1632-42.

Rishi, B. (2010), Motivators and decisional influencers of online shopping, International Journal of Business Innovation and Research, Vol. 4, No. 3, pp. 195-209.

Rogers, E. M. and Rogers, E. (2003), Diffusion of Innovations, Free Press, New York.

Roselius, T. (1971), Consumer Rankings of Risk Reduction Methods, Journal of Marketing, Vol. 35, No. 1, pp. 56-61.

Seth, J. N. and Sisodia, R. S. (1997), Consumer behavior in the future, in: Peterson R. (ed.), Electronic Marketing and the Consumer, pp. 17-37, Sage Publications, Thousand Oaks, CA.

Sitkin, S. B. and Pablo, A. L. (1992), Re-conceptualizing the determinants of risk behavior, The Academy of Management Review, Vol. 17, No. 1, pp. 9-39.

Sözer, E. G. (2009), Postmodern Pazarlama: Marka Çaðýnda Liderlik Ýçin PIM Modeli, Beta, Istanbul.

Straub, D., Keil, M. and Brenner, W. (1997), Testing the Technology Acceptance Model Across Culture: A Three Country Study, Information \& Management, Vol. 33, No. 1, pp. 1-11.

Swaminathan, V., Lepkowska-White, E. and Rao, B. P. (1999), Browsers or Buyers in Cyberspace? An Investigation of Factors Influencing Electronic Exchange, Journal of Computer-Mediated Communication, Vol. 5, No. 2, pp. 1-24.

Swinyard, W. R. and Smith, S. M. (2003), Why people (don't) shop online: A lifestyle study of the internet consumer, Psychology \& Marketing, Vol. 20, No. 7, pp. 567-597.

Szymanski, D. M. and Hise, R. T. (2000), E-satisfaction an initial examination, Journal of Retailing, Vol. 76, No. 3, pp. 309-322.

Taylor, J. W. (1974), The role of risk in consumer behavior, Journal of Marketing, Vol. 38, No. 2, pp. 54-60.

TUIK- Turkish Statistics Association. (2012), Internet Usage Statistics 2011 (Online), TUIK, Ankara. Available at http://www.tuik.gov.tr (Accessed on April 2012). 
Turan, A. H. (2012), Internet Shopping Behavior of Turkish Customers: Comparison of Two Competing Models, Journal of Theoretical and Applied Electronic Commerce Research, Vol. 7, No. 1, pp. 77-93.

U.S. Commerce Department. (2012), E-Commerce Statistics 2011 (Online), U.S. Commerce Department, Washington, D.C. Available at http://www.commerce.gov (Accessed on April 2012).

U.S. Census Bureau. (2011), E-Stats Report 2010 (Online), U.S. Census Bureau, Washington, D.C. Available at http://www.census.gov (Accessed on May 2012).

Website Magazine. (2012), News Section (Online), Website Magazine, Illinois. Available at http:// www.websitemagazine.com (Accessed on April 2012).

Vijayasarathy, L.R. and Jones, J.M. (2000), Print and Internet catalog shopping: assessing attitudes and intentions, Internet Research, Vol. 10, No. 3, pp. 191-202.

Yasin, N. M., Noor, M. N. and Mohammad, O. (2007), Does image of country-of-origin matter to brand equity?, Journal of Product \& Brand Management, Vol. 16, No. 1, pp. 38-48.

Yavas, U. (2003), A multi-attributes approach to understanding shopper segments, International Journal of Retail \& Distribution Management, Vol. 31, No. 11, pp. 541-548.

Zhang, X and Prybutok, V. (2003), TAM: The Moderating Effect of Gender on Online Shopping, Journal of International Technology and Information Management, Vol. 12, No. 2, pp. 99-118. 